\title{
DEKONSTRUKSI MAKNA JIHAD DALAM NOVEL LASKAR MAWAR KARYA BARBARA VICTOR
}

\author{
Nadya Afdholy \\ Universitas Airlangga \\ nadyaafdholy@yahoo.com
}

\begin{abstract}
ABSTRAK
Penelitian ini berfokus pada analisis novel yang berjudul Laskar Mawar karya Barbara Victor dengan memanfaatkan teori dekonstruksi dari Jacques Derrida. Penelitian ini bertujuan mendekonstruksi makna jihad dalam novel Laskar Mawar karya Barbara Victor. Anjuran untuk mencintai tanah air, membela, dan menegakkan agama mendorong masyarakat Palestina untuk berjihad, namun jihad yang dimaksud bermakna sempit, yaitu dengan melakukan bom bunuh diri. Pembongkaran makna jihad yang dimunculkan dalam novel terlihat melalui para jihadis yang terlibat dalam tindakan bom bunuh diri di Palestina. Penelitian ini merupakan penelitian deskriptif kualitatif. Data yang digunakan adalah novel Laskar Mawar karya Barbara Victor. Penelitian ini menggunakan teknik pengumpulan data dengan pencatatan dan menggunakan teknik analisis data dengan pembacaan secara menyeluruh. Hasil dari penelitian ini menunjukkan pembongkaran terhadap makna jihad sehingga melahirkan makna jihad yang baru, yaitu jihad bom bunuh diri. Pemaknaan baru mengenai jihad tersebut jika ditinjau dari sisi humanisme berpotensi menyesatkan karena bertentangan dengan nilai dasar kemanusiaan dan nilai universal agama.
\end{abstract}

Kata Kunci: dekonstruksi, jihad, novel

\section{ABSTRACT}

This study focuses on the analysis of a novel entitled Laskar Mawar by Barbara Victor by utilizing the deconstruction theory of Jacques Derrida. This study aims to deconstruct the meaning of jihad in the novel Laskar Mawar by Barbara Victor. Suggestion for loving the homeland, defending, and upholding religion encourage the Palestinian people to do jihad, but the jihad in question is narrow, namely by committing suicide bombings. The dismantling of the meaning of jihad that appears in the novel is seen through the jihadists involved in suicide bombings in Palestine.

This research is a qualitative descriptive study. The data used is the Laskar Mawar novel by Barbara Victor. This study uses data collection techniques by recording and using data analysis techniques with a thorough reading. The results of this study show the dismantling of the meaning of jihad which gave birth to the meaning of a new jihad, namely jihad suicide bombings. The new meaning of jihad if viewed from the side of humanism has the potential to be misleading because it contradicts the basic human values and universal values of religion.

Keywords: deconstruction, jihad, novels 
Fenomena tentang jihad di dalam novel Laskar Mawar karya Barbara Victor merupakan sebuah ideologi yang dilakukan oleh golongan muslim radikal di negara Palestina. Isu tersebut menjadi menarik untuk diteliti karena jihad di dalam novel Laskar Mawar karya Barbara Victor merupakan sebuah pandangan yang tidak sesuai dengan makna jihad yang sesungguhnya. Anjuran untuk mencintai tanah air dan membela agama mendorong masyarakat di Palestina melakukan jihad. Jihad yang dimaksud dalam hal ini menjadi sempit maknanya, yaitu jihad dengan menggunakan bom yang diledakkan untuk membunuh diri sendiri dengan harapan dapat memusnahkan tank-tank Israel. Oleh karena itu, tidak sedikit umat Islam yang berpandangan bahwa jihad identik dengan perang atau kekerasan. Hal tersebut menjadikan Islam di mata dunia Barat dipandang sebagai agama perang atau agama kekerasan.

Novel Laskar Mawar karya Barbara Victor memaparkan kisah tentang empat perempuan yang mati demi alasan-alasan yang melampaui cita-cita pembebasan Palestina. Keempat tokoh perempuan tersebut ingin menunjukkan eksistensinya dalam membela negara sebagai wujud cinta tanah air. Mereka menjemput kematian dengan cara ekstrem, yaitu dengan melakukan tindakan bom bunuh diri. Di dalam arena peperangan, seharusnya anak-anak dan perempuan tidak turut andil dalam peperangan dan tidak boleh dipersenjatai, karena yang idealnya berperang adalah laki-laki.

Triana mengungkapkan bahwa kasus kekerasan terhadap anakanak dan perempuan dalam peperangan dan konflik bersenjata sering dianggap sebagai peristiwa yang melampaui batas (Triana, 2009: 320). Anak-anak dan perempuan tidak memiliki hak untuk berperang. Tetapi, fakta dalam novel Laskar Mawar mengatakan sebaliknya, anak-anak dan perempuan justru menjadi korban, para perempuan kembali berperang dengan melakukan tindakan bom bunuh diri. Hal tersebut didukung oleh pemerintah, bahkan hal tersebut didoktrin sebagai jihad. Dalam hal ini, makna jihad dalam novel Laskar Mawar didekonstruksi dengan makna baru yang belum pernah muncul sebelumnya.

Dekonstruksi makna jihad yang sangat menonjol terlihat pada maknanya yang telah dipersempit melalui aksi bom bunuh diri oleh para jihadis perempuan. Menurut Haryatmoko, bentuk penelusuran dekonstruksi memperlihatkan hal-hal yang disembunyikan oleh sejarah atau yang dilarangnya dengan menyusun kembali sejarah melalui beberapa unsur yang ditindas (Haryatmoko, 2016: 133). Dalam hal ini makna jihad yang konon bertujuan mulia untuk mendapatkan derajat tertinggi di sisi Tuhan dibongkar dengan cara memunculkan makna baru mengenai jihad yang condong pada kekerasan.

Fenomena dalam novel Laskar Mawar karya Barbara Victor memiliki karakter menarik untuk dikaji dalam mengusung permasalahan jihad bom bunuh diri, yaitu tindakan bom bunuh diri tidak dibenarkan dalam Islam, namun dalam novel Laskar Mawar tindakan tersebut didoktrin sebagai jihad. Sumbulah mengatakan bahwa Islam didoktrin sebagai agama anti kekerasan, namun fakta 
penakhlukan dalam historiografi Islam yang lebih terkenal dengan sebutan futuhat atau pembebasan, terutama mulai abad tujuh juga menggandeng kekerasan (Sumbulah, 2005: 1). Melakukan tindak bom bunuh diri berarti telah melaksanakan jihad atau perang suci di jalan Allah, dengan melibatkan diri dalam aksi bom bunuh diri tersebut berarti telah berjihad di jalan Allah.

Berdasarkan permasalahan yang dipaparkan pada latar belakang tersebut, maka rumusan masalah dalam penelitian ini adalah bagaimanakah dekonstruksi makna jihad di dalam novel Laskar Mawar karya Barbara Victor? Adapun tujuan penelitian ini adalah mendekonstruksi makna jihad di dalam novel Laskar Mawar karya Barbara Victor.

Fenomena mengenai jihad direfleksikan secara gamblang dalam beberapa novel, mengingat novel adalah karya yang merupakan cermin dari sebuah realitas kehidupan sosial masyarakat (Wellek, 2014: 111). Empat karya yang mengupas seputar jihad di antaranya: Pertama, novel yang berjudul Pengantin Bom (2009) karya Sidik Jatmika. Novel ini menceritakan seseorang bernama Gesang yang mengorbankan nyawanya dengan cara yang menyayat hati, yaitu dengan meledakkan dirinya bersama bom yang dililitkan ke tubuhnya dengan tujuan untuk mengutarakan propaganda politik. Selain itu, hal tersebut bertujuan untuk menciptakan kerusakan sebesar-besarnya sehingga memakan banyak korban. Tokoh utama dalam novel Pengantin Bom meminjam pandangan agama untuk melegitimasi tindakannya sebagai pelaku tindak bom bunuh diri. Dengan melakukan tindakan bom bunuh diri diharapkan dapat mengajak dan mengonstruksi cara pandang orang lain untuk melakukan hal yang sama seperti dirinya.

Kedua, novel yang berjudul Jihad Terindah (2007) karya Muhtadi Muntaha. Novel ini mengisahkan tentang nilai-nilai universal Islam di tengah keberagaman persepsi sempit dan hedonistik manusia terkait sebab-sebab kemunculan pelaku teroris lewat aksi bom bunuh diri, salah satunya adalah sistem intelijen negara yang dianggap bekerja tidak optimal. Munutaha menarasikan seputar kecacatan Yahudi yang menurutnya memiliki saham dalam menghasilkan para eksekutor bom bunuh diri di belahan dunia.

Ketiga, novel yang berjudul Demi Allah Aku Jadi Teroris (2009) karya Damien Dematra. Novel ini menceritakan tentang proses radikalisme dalam agama seorang mahasiswi oleh kelompok radikal dan kelompok teroris yang berencana melakukan aksi bom bunuh diri atas nama jihad. Tokoh utama dalam novel ini adalah seorang perempuan Muslim bernama Kemala yang kuliah di jurusan kedokteran yang kemudian menjadi militan pada kelompoknya dan bersedia melakukan jihad dengan cara bom bunuh diri. Kemala melakukan aksi terornya di Jakarta untukmembunuh non-Muslim yang dianggap kafir, tetapi rencana tersebut digagalkan oleh seorang polisi anti teror yang jatuh cinta padanya. 
Fenomena jihad dalam ketiga novel tersebut bertemakan kepahlawanan yang bersifat brutal. Semangat jihad yang dinarasikan dalam ketiga novel tersebut dimaknai secara dangkal dengan bentuk yang anarkis. Para tokoh dalam ketiga novel tersebut melakukan tindakan jihad bom bunuh diri dalam bingkai agama. Tindakan tersebut dilakukan sebagai pembela kebenaran dan untuk memerangi kemaksiatan. Tema jihad bom bunuh diri diperkenalkan kembali dalam novel Laskar Mawar karya Barbara Victor dengan motif yang berbeda dengan ketiga novel tersebut.

Jihad memiliki berbagai makna menurut beberapa ahli. Secara bahasa, jihad berasal dari kata dasar jahada, yajhadu, al-juhdu, aljahdu yang memiliki lebih dari 20 makna (Al Uyairi, 2007: 13). Semua makna dari asal kata jihad tersebut berkisar pada makna kemampuan, kesulitan, keluasan, perang, dan bersungguh-sungguh. Para ahli seperti ahli tafsir, ahli hadits, ahli fikih, dan ahli mengartikan jihad secara bahasa dengan makna mencurahkan seluruh kemampuan atau bersungguh-sungguh dalam menundukkan kesulitan.

Secara syariat dalam Alquran dan As Sunnah melafalkan jihad dari makna bahasa yang sangat luas menuju sebuah makna yang khusus dan memberi batasan mengenai makna jihad hanya untuk makna khusus tersebut, Al Uyairi menyebutkan makna jihad secara syariat dalam bukunya yang berjudul Muslimah Berjihad yang berarti mengerahkan segenap kampuan dan bersungguh-sungguh dalam berperang di jalan Allah (Al Uyairi, 2007: 15). Perang yang dimaksud yaitu perang baik secara langsung yang berupa kontak fisik maupun perang secara tidak langsung seperti membantu proses perang dengan harta, pikiran, memperbanyak jumlah pasukan, dan lain sebagainya.

Dalam menganalisis novel Laskar Mawar karya Barbara Victor, peneliti menggunakan teori dekonstruksi Derrida. Dalam penelitian ini dilakukan analisis dekonstruksi terhadap makna jihad dalam novel Laskar Mawar karya Barbara Victor. Untuk melakukan analisis dekonstruksi terhadap makna jihad tersebut, peneliti memaparkan oposisi biner yang terdapat dalam novel Laskar Mawar karya Barbara Victor yang berkaitan dengan jihad. Kemudian oposisi biner tersebut dimaknai kembali dengan makna yang baru yang kemunculannya ditunda sebelumnya, selanjutnya diinterpretasikan secara kritis dan lebih mendalam.

Dekonstruksi Derrida dipahami sebagai bentuk pengambilan jarak yang agresif, seperti: mengguncang, memindah, membongkar, menghancurkan, mempertanyakan teks (Haryatmoko, 2016: 133). Dekonstruksi diragukan oleh banyak pemikir karena kesannya hanya memporakporandakan pemaknaan. Menurut Goldschmit, "tanpa bisa menertawakan diri sendiri, dekonstruksi tidak akan terwujud" (Goldschmit, 2003: 229). Berdasarkan pernyataan tersebut, virus dekonstruksi telah menelusup sejak pembentukan teks. Dekonstruksi tidak terelakkan dan suatu saat akan beroperasi karena merupakan prinsip intern dari teks. Diperlukan sikap dewasa 
dalam melakukan dekonstruksi, seperti menertawakan diri sendiri, agar hal tersebut dapat membawa hasil.

Istilah pengambilan jarak digunakan dengan alasan karena konsep tersebut dapat menjelaskan prosedur pembongkaran teks sebagai unsur yang melekat pada prinsip intern teks (Haryatmoko, 2016: 135). Dekonstruksi beraksi seperti virus yang menyebar dan membongkar sejak sebelum semua perakitan tekstual atau institusional. Dekonstruksi bukan segala sesuatu yang bermula dari luar teks. Menurut Klages, dekonstruksi dianggap mengusik kekuatan-kekuatan yang menentukan pemaknaan di dalam teks itu sendiri (Deutscher, 2006: 59). Hal tersebut dapat dimaknai bahwa dekonstruksi membaca teks untuk melihat teks sebagai pusat yang kemudian dikonstruksi sistem kebenaran dan pemaknaannya. Setiap teks menciptakan dunianya dengan istilah-istilah dan premispremisnya sendiri.

Gagasan dasar dekonstruksi adalah untuk melihat apa yang terjadi terhadap strukturnya bila suatu konsep dihilangkan (Haryatmoko, 2016: 136). Fungsi pusat teks yaitu unutk membatasi permainan, menjamin konsep-konsep tetap dalam relasi ketat yang satu dengan yang lainnya, sehingga pembaca mengtahui hakikat masing-masing. Jadi, dilihat dari posisi positifnya, dekonstruksi merupakan cara membaca teks dengan cara memngguncang struktur teks agar terrjadi permainan yang lebih banyak dan lebih mudah membongkar ambiguitas makna, yang kemudian hal tersebut berarti bahwa oposisi biner tidak lagi berhenti dengan rapi pada sisi kutub yang dianggap pasti. Dengan demikian, dekonstruksi mempertanyakan pemaknaan yang dianggap sudah pasti.

Konsep differance (penundaan atau pembalikan) menggambarkan arah dekonstruksi dengan cara menunda hubungan penanda dan petanda, yaitu dengan membalikkan logika biner. Defferance dalam bahasa Perancis seharusnya berakhiran "-ence", tetapi Derrida menggunakan "-ance" untuk menunjukkan peleburan dua mana kata kerja differer, yang artinya berbeda dan menunda (Haryatmoko, 2016: 137). Penggantian huruf tersebut menunjukkan bahwa ucapan yang dari kacamata metafisik dianggap prioritas justru tidak mampu melukiskannya. Differance merupakan perbedaan yang dicabut dari logika biner sehingga bisa bermakna baru, sekaligus sama dan berbeda. Makna baru tersebut kemudian menghancurkan kultus identitas dan merupakan strategi baru untuk meraih kembali perbedaan.

Asumsi dasar dari dekonstruksi adalah bahwa setiap teks yang 'mapan' (logika penghadap-hadapan teks) bersembunyi kepentingan dominasi di dalamnya. Dalam setiap reproduksi teks (kata) dalam masyarakat, sesungguhnya bersembunyi relasi kuasa di dalamnya yang terus menerus berusaha melepaskan diri, sekaligus mencoba menemukan pusat-pusat baru. Dalam menemukan pusat baru, subjek akan terlibat dengan adanya satu pusat, tapi kesadaran akan pusat plural, bukan tunggal. 
Cara kerja teori deskronstruksi secara operasional melalui pembacaan ganda atas teks, yakni mengajukan termininologi teks yang bersifat binner, dan memperlihatkan kelemahan-kelemahan dalam teks. Kaitannya dengan kajian ini, dekonstruksi digunakan untuk membongkar dan memunculkan makna baru mengenai jihad.

\section{METODE}

Jenis penelitian ini merupakan penelitian deskriptif kualitatif. Penyajian dilakukan dengan cara mendeskripsikan kata-kata untuk mendapatkan pemahaman mengenai fenomena yang diteliti. Dalam hal ini, pemahaman dilakukan pada fenomena jihad bom bunuh diri dalam novel Laskar Mawar karya Barbara Victor. Penelitian kualitatif yaitu penelitian yang digunakan untuk menginterpretasikan data dengan memberi arti pada data yang diperoleh, mengubah atau membuat data-data tersebut agar dapat dimengerti (Neuman, 2004: 148). Penelitian kualitatif memiliki strategi penelitian yang spesifik terkait dengan pengumpulan dan analisis data, dan juga laporan penelitian berdasarkan berbagai disiplin keilmuan yang berkembang dinamis selama proses penelitian. Seperti pendapat Creswell yang menyatakan bahwa strategi penelitian yang spesifik dalam pendekatan kualitatif berdasarkan berbagai macam disiplin ilmu terus berkembang selama proses penelitian (Creswell, 2009: 263). Dengan demikian, strategi penelitian dalam penelitian kualitatif terus menerus berkembang berdasarkan berbagai macam disiplin ilmu selama proses penelitian.

Proses penelitian kualitatif melibatkan beberapa pertanyaan yang sudah dimunculkan, seperti dengan cara mengumpulkan data menurut partisipan atau pemeran serta; menganalisis data secara induktif, mengelola data dari data yang spesifik menjadi tema umum, kemudian menafsirkan makna di balik data. Laporan yang dihasilkn memiliki struktur penulisan yang fleksibel (Creswell, 2009: 352). Menurut Moleong, peneitian kualitatif adalah pemahaman fenomena tentang yang dialami oleh subjek penelitian, seperti pelaku, persepsi, motivasi, tindakan, dan lain sebagainya yang secara holistik dengan cara deskripsi dalam bentuk kata-kata pada konteks dan metode yang alamiah (Moleong, 2007: 6).

Objek dalam penelitian ini adalah novel Laskar Mawar karya Barbara Victor yang diterbitkan dan diterjemahkan oleh PT Mizan Pustaka, cetakan pertama (2008). Dipilihnya novel terjemahan, dikarenakan novel terjemahan dapat dipahami secara kontekstual oleh masyarakat Indonesia. Novel ini terdiri atas xxxi dan 399 halaman. Data yang digunakan dalam novel tersebut hanya datadata yang merefleksikan dekonstruksi mengenai makna jihad dalam teks novel Laskar Mawar yang didapatkan melalui dialog, monolog, pemikiran, perilaku tokoh, maupun keterangan langsung yang diberikan penulis.

Pengumpulan data dalam penelitian ini dilakukan dengan empat tahap, yaitu: Pertama, data dalam penelitian ini ditentukan berdasarkan fokus penelitian yaitu mengkaji dekonstruksi jihad yang maknanya dimunculkan kembali sebagai jihad bom bunuh 
diri. Kedua, bentuk data dalam penelitian ini adalah kutipan-kutipan dalam novel Laskar Mawar karya Barbara Victor yang berfokus pada dekonstruksi jihad. Ketiga, peneliti menyeleksi data-data tersebut dengan teknik close reading atau membaca secara mendalam (komprehensif), menyimak, dan mencatat, sehingga data yang digunakan hanya yang sesuai dengan fokus kajian penelitian. Keempat, peneliti mengabsahkan data atau reliabilitas data sesuai dengan fokus kajian penelitian, yaitu dekonstruksi.

Teknik analisis data dalam penelitian novel Laskar Mawar karya Barbara Victor ini dilakukan dalam empat tahap, di antaranya: Pertama, peneliti membaca novel Laskar Mawar karya Barbara Victor sebagai data primer secara menyeluruh, kemudian menelusuri oposisi biner mengenai makna jihad. Kedua, peneliti melakukan coding, yang merupakan proses mengorganisasi data menjadi potongan-potongan kecil sebelum mencari makna dari keseluruhan teks, seperti mengambil kutipan-kutipan dari novel Laskar Mawar karya Barbara Victor dan memasukkannya sesuai kategori, kemudian menerapkannya sesuai dengan landasan teori, yaitu dekonstruksi. Ketiga, peneliti memperoleh sebuah deskripsi dari data coding yang telah dilakukan pada tahap dua. Deskripsi yang diperoleh termasuk informasi mendetail mengenai tokoh, tempat, dan peristiwa dalam sebuah setting yang diperkuat dengan beberapa kutipan sebagai bukti. Keempat, peneliti melakukan analisis secara menyeluruh mengenai makna di balik pembongkaran jihad dan menginterpretasi semua data yang diperoleh. Kemudian, ditarik kesimpulan dari analisis-analisis yang telah dilakukan terhadap novel tersebut.

\section{PEMBAHASAN Jejak Konstruksi Jihad dalam Novel Laskar Mawar Karya Barbara Victor}

Masyarakat Palestina adalah masyarakat yang masih menganut patriarki yang agama dan kulturnya saling berkaitan seperti kebanyakan masyarakat Arab lainnya. Masyarakat Palestina bukan masyarakat yang individualis, mereka sangat mengedepankan kesejahteraan masyarakatnya. Hal tersebut terlihat dalam kutipan novel berikut,

Dalam masyarakat ini, agama dan kultur berjalan beriringan, tak ada pemisahan. Hal-hal yang diperbolehkan dalam agama, diperbolehkan pula oleh kultur. Tak ada yang ditolak, bahkan dianggap sebagai ketentuan yang suci. (Victor, 2008: 237)

Berdasarkan kutipan novel tersebut, maka dapat diketahui bahwa terdapat keterkaitan antara agama dan kultur dalam masyarakat Palestina. Keduanya merupakan ketentuan yang dianggap suci, yang secara tidak disadari merupakan muara sebuah masalah baru. Ketentuan agama dijadikan pedang untuk membuat kerusakan di bumi Palestina demi kepentingan suatu kelompok atau komunitas yang berkaitan dengan kelangsungan hidup masyarakat di sana. 
Keluarga adalah bagian terpenting bagi masyarakat Palestina. Hubungan antara anggota keluarga didominasi oleh norma agama dan tradisi yang turun temurun. Relasi antara anggota keluarga inti dan keluarga lainnya sangat dijaga, bahkan mereka peduli dengan kesejahteraan dan keselamatan keluarga lainnya. Hal tersebut dapat dilihat dalam kutipan berikut ini,

Pada dasarnya, jika kita menyentuh seorang perempuan untuk memeriksanya," katanya, berarti kita telah mengganggu kehormatannya, yang kemudian akan berpengaruh pada keluarganya; dan akhirnya, seluruh desa akan merasa bahwa mereka turut bertanggung jawab untuk membela kehormatannya. (Victor, 2008: 7)

Kutipan tersebut menunjukkan bahwa masyarakat Palestina terutama perempuannya sangat dijaga kehormatannya. Hal tersebut bukan hanya tanggung jawab keluarga inti, tetapi juga tanggung jawab seluruh desa. Norma agama dan tradisi mendominasi hubungan antara anggota keluarga yang satu dengan yang lain. Bahkan ketika perempuan akan diperiksa, tidak diperbolehkan menyentuhnya barang sedikit pun, karena hal tersebut dianggap pelecehan terhadap perempuan.

Perempuan Palestina memiliki peran yang sangat terikat oleh peran domestik. Seperti kebanyakan masyarakat Arab lainnya, peran mereka di ranah publik sangat terbatas. Peran utama mereka adalah di rumah, berkutat dengan urusan rumah tangga. Ketaatan kepada seorang ayah dan suami merupakan salah satu indikator tertinggi kehormatan dalam kehidupan perempuan Palestina, karena seorang suami diperumpamakan sebagai pengemudi mobil seperti yang terlihat dalam kutipan berikut.

Ahmed berkata, "Dalam lembaga perkawinan, suami bagaikan seorang pengemudi mobil. Ia memegang kendali dan ialah yang menetapkan aturan-aturan yang akan memimpin keluarga menuju keharmonisan dan kebahagiaan. Ketika terjadi permasalahan yang harus ditangani, Allah telah menetapkan hukum atau petunjuk yang bisa dijadikan acuan seorang suami jika istrinya tidak taat." (Victor, 2008: 51-52)

Seorang suami dalam kutipan tersebut adalah sosok yang memegang kuat kendali dalam sebuah keluarga, bahkan norma agama menetapkan hukum sebagai acuan mengenai bagaimana jika seorang istri tidak menaati suaminya. Dalam masyarakat Palestina, semua kekuasaan adalah milik suami karena suami bertanggung jawab penuh sebagai pemimpin atas keharmonisan dan kebahagiaan yang akan diraih keluarganya. Namun, bagi perempuan Palestina yang belum menikah, maka pengemudinya adalah ayah dan kakak atau adik laki-lakinya.

Semua perempuan Palestina diharapkan untuk menjaga reputasi keluarga dan kehormatannya yang terhubung dengan perilaku seksual perempuan. Jika seorang perempuan berperilaku tidak sopan atau bahkan mencemarkan nama baik keluarga dengan 
perilaku seksual, maka dia menyebabkan aib bagi semua kerabatnya, seperti menggunakan pakaian tidak senonoh, atau terlihat tanpa menggunakan jilbab dengan laki-laki yang bukan muhrimnya, hamil di luar nikah, dan lain sebagainya. Hal tersebut dinarasikan dalam kutipan berikut.

Kepemimpinan Hamas mengeluarkan peraturan resmi bahwa perempuan dilarang keluar ke tempat umum tanpa menutup kepala mereka dengan hijab (kerudung) dan memakai jilbab (blues dan rok yang panjang)," kata Kolonel Harrari. Para ayah dan saudara laki-laki diperintahkan untuk mengawasi tingkah laku kerabat perempuan mereka dengan sangat ketat. (Victor, 2008: 6)

Aturan mengenai perlengkapan perempuan yang harus mereka kenakan untuk pergi keluar rumah sangat jelas. Hamas (Harakah Muqawwamah Islamiyah) meresmikan peraturan untuk perempuan untuk menutup aurat mereka dan jangan sampai perempuan berpakaian tidak senonoh jika bepergian. Kerudung, blus, dan rok panjang harus digunakan dengan tepat sebelum mereka menginjakkan kaki keluar dari rumah. Jika peraturan tersebut tidak dipatuhi, maka akan ada sanksi selain mendapat aib dalam keluarga tersebut, yaitu terjadinya perbedaan pendapat antara Hamas dan penduduk Palestina yang berdampak pada kependudukan Israel. Israel akan dengan mudah menghancurkan perlawanan Palestina. Selain itu, aturan sosial dan agama yang ketat juga tercermin seperti dalam kutipan berikut,

Saat ini, perempuan Palestina yang tidak menikah hidup di bawah serangkaian aturan sosial dan agama yang ketat: jika berpendidikan terlalu tinggi, ia dianggap abnormal; jika memandangi laki-laki, ia terancam dikucilkan; jika menolak menikah, ia dianggap akan lepas kendali; jika tidur dengan laki-laki, khususnya jika hamil, ia adalah aib bagi keluarga dan bisa mati di tangan kerabat laki-lakinya. (Victor, 2008: 257)

Kutipan tersebut mendeskripsikan betapa ketatnya aturan sosial dan agama dalam masyarakat Palestina kepada perempuan di sana. Tersirat bahwa gerak-gerik perempuan sangat diawasi. Perempuan di Palestina masih digolongkan ke dalam masyarakat tradisional yang idealnya tidak boleh berpendidikan terlalu tinggi, tidak boleh menolak ketika ada yang berniat menikahinya. Pergaulan antara laki-laki dan perempuan pun sangat dijaga. Jika seorang perempuan dinyatakan hamil sebelum menikah, maka darahnya halal bagi saudara laki-lakinya. Artinya, kakak atau adik laki-laki perempuan tersebut diperbolehkan membunuhnya karena telah menjadi sebab aib keluarga.

Negara Palestina merupakan negara berkonflik, yang akhirnya mengundang masyarakatnya untuk berjihad demi membela negara dan agamanya, terutama laki-laki. Terlebih lagi, mati syahid sebagai imbalan semakin membakar semangat masyarakatnya 
untuk berbondong-bondong melakukan jihad. Jihad terbagi menjadi berbagai macam, seperti bekerja keras membanting tulang, menuntut ilmu, merawat anak, melindungi keluarga dari marabahaya, pergi umroh, naik haji, dan perang. Namun, jihad yang paling cocok untuk negara berkonflik adalah perang menggunakan senjata untuk melawan musuh-musuhnya. Tentunya, senjata yang digunakan untuk berperang, seharusnya menggunakan teknologi yang canggih.

Dibandingkan negara Israel, Palestina kalah dalam berbagai hal, salah satunya di bidang teknologi. Negara Israel dibantu oleh negara-negara maju, sehingga Israel memiliki perlengkapan perang yang lebih canggih, sedangkan negara Palestina memiliki perlengkapan perang yang terbatas bahkan akses yang minim, maka dari itu mereka membutuhkan alat yang sederhana namun efektif, seperti bom rakitan. Perlengkapan dan alat yang digunakan untuk merakit bom dapat ditemukan dengan mudah. Sehingga masyarakat Palestina menganggap bom sebagai jawaban dari keterbatasan uang dan teknologi.

Bunuh diri sebenarnya dilarang keras oleh agama. Islam lebih lanjut mengajarkan bahwa jihad tidak memperbolehkan dengan membunuh maupun dengan bunuh diri untuk menimbulkan rasa sakit atau bahkan kematian terhadap orang lain, seperti yang termaktub dalam ayat berikut.

Hai orang-orang yang beriman, janganlah kamu saling memakan harta sesamamu dengan jalan yang batil, kecuali dengan jalan perniagaan yang berlaku dengan suka sama suka di antara kamu. Dan janganlah kamu membunuh dirimu; sesungguhnya Allah adalah Maha Penyayang kepadamu. (4: 29)

Ayat tersebut menggambarkan bahwa jihad bukanlah dengan cara menghilangkan nyawa meskipun untuk mempertahankan Islam, namun dua ayat Alquran berikut menyatakan sebaliknya:

Hai orang-orang yang beriman, apakah sebabnya bila dikatakan kepadamu: "Berangkatlah (untuk berperang) pada jalan Allah" kamu merasa berat dan ingin tinggal di tempatmu? Apakah kamu puas dengan kehidupan di dunia sebagai ganti kehidupan di akhirat? Padahal kenikmatan hidup di dunia ini (dibandingkan dengan kehidupan) di akhirat hanyalah sedikit. (9: 38)

Jika kamu tidak berangkat untuk berperang, niscaya Allah menyiksa kamu dengan siksa yang pedih dan digantinya (kamu) dengan kaum yang lain, dan kamu tidak akan dapat memberi kemudharatan kepada-Nya sedikitpun. Allah Maha Kuasa atas segala sesuatu. (9: 39)

Kedua ayat tersebut tidak hanya menganjurkan berjihad, tetapi mewajibkan jihad bagi setiap muslim. Berdasarkan dalil-dalil di atas dapat disimpulkan bahwa jihad di jalan Allah digambarkan secara tidak terbatas, namun berjihad melawan non muslim selalu 
menjadi bagian besar dari makna jihad itu sendiri. Terdapat kontradiksi yang jelas, antara tidak diperbolehkan bunuh diri karena itu merupakan dosa besar, tetapi membunuh untuk menyakiti non muslim merupakan kesalehan yang mendalam. Agama merupakan dimensi utama dari eksistensi manusia, jihad dan syahid dalam membela negara, sekarat dalam proses berjihad untuk Allah atau bahkan kematian yang dilakukan dengan sukarela secara sadar, dianggap membela agama.

Konsep jihad di Palestina terkait dengan pendudukan, kemerdekaan, dan kebebasan beragama. Sejak intifada pertama yang terjadi pada tahun 1987 telah ditemukan banyak martir yang harus keluar dari universitas karena kesulitan ekonomi atau dipaksa mencari pekerjaan di usia muda untuk membantu keluarga mereka (Gambetta \& Hertog, 2016: 41). Hal tersebut merupakan penggambaran situasi yang darurat akibat pendudukan Israel di wilayah Palestina bagi umat Islam Palestina. Hal tersebut juga merupakan deprivasi yang membuat semua bentuk jihad yang bermula dari keinginan merdeka hingga munculnya tindakan bom bunuh diri menjadi dilegalkan oleh pemerintah dengan harapan menuju kemerdekaan masyarakat Palestina dari jajahan negara Israel.

Di dalam arena peperangan, seharusnya anak-anak dan perempuan tidak turut andil dalam peperangan, bahkan tidak diperbolehkan dipersenjatai. Anak-anak dan perempuan tidak boleh diserang karena stereotipe perempuan yang lemah lembut dan anakanak yang belum memiliki kesadaran secara penuh. Konstruksikonstruksi tersebut mengandung statement bahwa konstruksikonstruksi tersebut didukung oleh para tokoh jihadis dengan melakukan tindakan bom bunuh diri yang didoktrin sebagai jihad dan dilakukan oleh perempuan.

\section{Dekonstruksi Makna Jihad dalam Novel Laskar Mawar Karya Barbara Victor}

Novel Laskar Mawar karya Barbara Victor membongkar konstruksi mengenai makna jihad yang selama ini dipahami sebagai sesuatu yang sakral. Dalam novel ini terdapat semacam gugatan melalui teks-teks, sehingga ditemukan makna baru mengenai jihad sebagai sesuatu yang profan, tidak lagi sakral. Berikut pembongkaran oposisi biner dalam novel Laskar Mawar karya Barbara Victor dan makna di balik pembongkaran tersebut.

Dalam novel Laskar Mawar karya Barbara Victor terdapat beberapa teks yang menunjukkan adanya operasionalisasi oposisi biner. Operasionalisasi yang ada dalam teks-teks tersebut tidak hanya dimunculkan seperti yang selama ini diketahui, tetapi dimunculkan dengan pengaburan, pembalikan, dan beberapa upaya dekonstruksi lainnya. Berikut pembongkaran oposisi biner yang dibagi menjadi dua, yaitu operasionalisasi oposisi biner dan profanisasi jihad. 


\section{A. Operasionalisasi Oposisi Biner Jihad dalam Novel Laskar Mawar Karya Barbara Victor}

Pada subbab ini, dipaparkan tiga operasionalisasi oposisi biner mengenai jihad yang terdapat dalam novel Laskar Mawar karya Barbara Victor, di antaranya: Pertama, Laki-laki versus Perempuan. Gagasan tradisional mengenai perempuan dan peranannya merupakan sebuah nilai yang dianggap biasa, mirip dengan masyarakat Arab lainnya, namun situasi perempuan Palestina berbeda dengan kehidupan masyarakat Arab. Kebanyakan perempuan dapat menikmati kebebasan dalam pergerakan politik dan pemberontakan atau perlawanan. Hal tersebut seperti yang terlihat dalam kutipan berikut ini,

Ini hanyalah permulaan. Perempuan-perempuan yang lain akan melakukan hal yang sama... Berperang dengan cara yang mampu kita lakukan, dan dengan cara apapun yang dilakukan kaum lelaki adalah hak dan sekaligus kewajiban kami. Seharusnya tak boleh ada perbedaan. Kami semua sama-sama menjadi korban kekuasaan pendudukan Israel. (Victor, 2008: 327)

Tidak dapat disangkal, dalam kutipan tersebut digambarkan bahwa pendudukan Israel terhadap Palestina membuat peran perempuan Palestina dalam masyarakat terlihat berbeda dengan perempuan lain yang sama secara tradisi Arab. Mereka menuntut kesetaraan atas kaum lelaki. Para perempuan juga turut andil dalam berperang seperti yang dilakukan oleh kaum lelaki, bahkan hal tersebut menjadi kewajiban bagi kaum perempuan. Mereka ingin dianggap sama dengan kaum lelaki, karena perempuan Palestina juga sama-sama menjadi korban atas pendudukan Israel.

Para laki-laki di Palestina berusaha meyakinkan para perempuan Palestina baik saudara, istri, maupun kerabat perempuan bahwa mati syahid merupakan jalan menebus kehormatan diri dan keluarga. Mereka meyakini hal tersebut dan memberikan pemahaman kepada para kaum perempuan agar memiliki paham yang sama seperti laki-laki seperti dalam kutipan berikut.

Yang membuatku terkejut ketika mewawancarai lelaki-lelaki ini, beberapa di antaranya di penjara, adalah bahwa dengan kekuasaan mereka yang sangat besar atas kaum perempuan, mereka semua berhasil meyakinkan saudara-saudara perempuan mereka, putri-putri dan istri-istri mereka, atau kerabat perempuan yang berada dalam perwalian mereka, bahwa karena "penyimpangan moral" yang telah mereka lakukan, atau kesalahan yang dilakukan oleh salah seorang anggota keluarga yang laki-laki, maka satu-satunya jalan untuk menebus kehormatan mereka dan keluarga mereka adalah dengan "mati syahid”. (Victor, 2008: xli)

Kutipan tersebut menjelaskan bahwa penyimpangan moral yang dilakukan oleh para laki-laki akan terhapus dengan cara 
menyerahkan diri mereka dalam aksi mati syahid. Dengan melakukan aksi bom bunuh diri, maka kehormatan keluarga, terutama kehormatan mereka akan terangkat, seberat apapun kesalahan yang pernah mereka perbuat sebelumnya. Dengan memberikan pemahaman yang sama kepada para kaum perempuan di Palestina, maka para laki-laki secara tidak langsung meminta kaum perempuan untuk turut andil dalam aksi tersebut. Kaum perempuan pun akhirnya mempunyai paham yang sama seperti laki-laki dan berusaha untuk memberanikan diri dan melibatkan dirinya dalam aksi mati syahid tersebut.

Terdapat sitiran kepada kaum perempuan di Palestina untuk berpartisipasi dalam aksi bom bunuh diri untuk melawan pendudukan Israel. Hal tersebut berarti terdapat kesetaraan antara laki-laki dan perempuan dalam hal berperang demi terciptanya negara Palestina yang bebas dari jajahan Israel. Perempuan dianjurkan untuk ikut berperang seperti yang terdapat dalam kutipan berikut.

Sambil dijaga oleh para pengawal dan penasihat setianya yang selalu siaga, dia menegaskan bahwa kaum perempuan tidak hanya diterima, tetapi juga diharapkan bisa berpartisipasi dalam perlawanan bersenjata menentang pendudukan Israel. "Perempuan dan laki-laki itu setara," begitu katanya sambil mengacungkan tangannya ke atas kepalanya dengan kedua jarinya membentuk simbol $V$ yang berarti victory - kemenangan. (Victor, 2008: 16)

Dalam kutipan tersebut, partisipasi kaum perempuan di Palestina dianggap sebagai kunci kemenangan bagi negara Palestina. Mereka tidak hanya diterima untuk setara dengan lakilaki, bahkan mereka memang disiapkan untuk berperang karena kondisi yang tidak stabil di negara tersebut. Semua memimpikan kemenangan. Semua merasa harus turut andil, tidak hanya laki-laki, perempuan pun juga ikut terjun dalam peperangan bersenjata. Kaum perempuan muslim di Palestina memproklamirkan mengenai kesyahidahan dan mereka mengatakan bahwa perempuan juga harus siap untuk turut serta dalam aksi bom bunuh diri seperti lakilaki. Hal tersebut terlihat dalam kutipan berikut.

Seorang perempuan yang menutupi wajah dan tubuhnya, sehingga mustahil untuk melihat wajahnya atau mengenali identitasnya, berbicara mengenai peran perempuan sebagai syahidah dan berkata bahwa perempuan harus siap untuk turut serta dalam aksi-aksi bom bunuh diri. (Victor, 2008: 33)

Berdasarkan kutipan tersebut, kaum perempuan di Palestina memperoleh peran yang utuh dan setara dengan laki-laki dalam perjuangan menentang pendudukan Israel. Hal tersebut dinyatakan kembali dalam kutipan berikut, "Kami siap untuk mati dalam jumlah yang sama dengan kaum laki-laki," katanya. (Victor, 2008: 33) Para kaum perempuan di Palestina menjadi siaga demi membela negaranya. Mereka tidak keberatan sedikit pun, meski 
sebenarnya hal tersebut melanggar tradisi, seperti dalam kutipan, "Menggunakan perempuan sebagai pelaku bom bunuh diri merupakan pelanggaran berat terhadap tradisi." (Victor, 2008: 89) Tradisi mengatakan bahwa peran perempuan seharusnya di ranah domestik, bukan di ranah publik. Sesuai tradisi, bom bunuh diri dilakukan oleh laki-laki muda yang berusia di bawah tiga puluh tahun. Hal tersebut terlihat dalam kutipan berikut.

Sesuai dengan tradisi Islam, pelaku aksi bom bunuh diri selalu laki-laki, di bawah tiga puluh tahun, taat beragama, belum menikah, paham betul tentang politik, dan tak bekerja. (Victor, 2008: 88)

Kutipan tersebut menyatakan bahwa tradisi Islam melegalkan aksi bom bunuh diri hanya untuk laki-laki yang masih muda, taat beragama, belum berkeluarga, memiliki paham politik di atas ratarata, dan tidak mempunyai pekerjaan. Perbedaan antara laki-laki dan perempuan dalam masyarakat Palestina berakar pada fundamentalisme atau paham yang cenderung untuk memperjuangkan sesuatu secara radikal yang bercokol kuat dalam konsep kesyahidan yang luar biasa di Palestina.

Walaupun para perempuan diizinkan untuk menjadi syahidah, banyak yang menyadari bahwa secara psikologis dan secara fisik perempuan dinilai kurang sempurna untuk melakukan misi mati syahid bom bunuh diri dibandingkan laki-laki. Hal tersebut menjadi peringatan keras mengingat kelemahan perempuan dibandingkan kekuatan laki-laki seperti dalam kutipan berikut,

"Laki-laki lebih efisien karena lebih pandai bersembunyi sambil membawa bom setelah menyeberangi Garis Hijau," katanya, "secara psikologis mereka lebih kuat dibandingkan perempuan, yang mungkin tidak kuat sembunyi berlama-lama sendirian dalam gelap, di kebun jeruk atau di tempat pembuangan sampah, atau di mana pun hingga saat serangan tiba." (Victor, 2008: 263)

Dalam kutipan tersebut, laki-laki dianggap cenderung efisien daripada perempuan untuk bersembunyi sambil membawa bom. Secara psikologis, laki-laki lebih kuat dibandingkan perempuan yang dianggap takut gelap, tidak mampu berlama-lama berada dalam kegelapan, bersembunyi di kebun jeruk, bersembunyi di tempat pembuangan sampah, atau pun di tempat-tempat persembunyian yang lainnya hingga saat serangan tiba.

Keikutsertaan perempuan sebagai pelaku aksi bom bunuh diri tidak hanya membuat segala sesuatunya lebih sulit bagi kestabilan keamaan Israel, namun berlaku juga bagi keamanan di seluruh dunia. Perempuan akan menjadi contoh yang berpotensi untuk mempermalukan laki-laki jika tidak turut andil, dan hal tersebut akan membuat banyak orang mau melakukan aksi bom bunuh diri seperti kutipan berikut, "Jika laki-laki melihat bahwa kaum perempuan ikut terlibat-akan lebih banyak orang yang mau melakukan aksi bom bunuh diri." (Victor, 2008: 326) 
Kedua, Privat versus Publik. Perempuan Palestina harus menjalani kehidupan pada dua sisi, yaitu sisi internal dan eksternal. Secara internal, mereka harus menghadapi tuntutan masyarakat yang tradisional seperti pada umumnya, sedangkan secara eksternal, seperti masyarakat Palestina pada umumnya, mereka dihadapkan oleh pendudukan Israel yang menimbulkan banyak pengaruh dalam keseharian mereka. Akibatnya, tatanan sosial masyarakat Palestina, budaya mengenai relasi gender, dan perilaku gender tertentu mendorong perempuan Palestina terlibat dalam misi bom bunuh diri, seperti dalam kutipan berikut.

Yang membuat orang lebih cepat ingin bunuh diri, yang membuatnya mencapai puncak yang tak dapat dibalikkan lagi, adalah alasan-alasan kultural atau sosial, yang menyebabkan proses perusakan diri ini berubah dengan cepat, dari sekadar teori menjadi kenyataan. (Victor, 2008: 331)

Berdasarkan kutipan tersebut, dapat disimpulkan bahwa tatanan sosial dan kultural merupakan faktor pendorong tergeraknya para perempuan Palestina melancarkan misinya terkait dalam bom bunuh diri. Pendudukan Israel di Palestina telah mengubah perempuan Palestina dan memaksa mereka untuk menjalani kehidupan di bawah pendudukan tersebut pada dua sisi, antara sisi internal dan eksternal. Mau tidak mau perempuan harus melanggengkan keduanya, bahkan jika pada akhirnya harus mengorbankan nyawanya sekaligus.

Identitas perempuan Palestina didefinisikan oleh peran tertentu yang telah ditentukan oleh masyarakat. Masyarakat dan budaya Palestina merupakan bagian yang tidak terpisahkan dari tradisi Islam. Status perempuan di Palestina berkiblat pada tradisi Islam dan Arab yang diinterpretasikan dalam konteks yang lebih luas. Seperti pada tradisi Arab lainnya, konteks sosio-budaya yang dianut oleh masyarakat Palestina menempatkan level tertinggi pada kehormatan keluarganya. Hal tersebut terlihat dalam kutipan berikut,

"Mereka dilarang keluar sendirian pada malam hari, berdemonstrasi, dan berhadapan dengan tentara." Lebih jauh ia menjelaskan bahwa perempuan diwajibkan untuk mengenakan baju yang panjang tradisional mereka yang membuat mereka tak bisa bergerak bebas, dan karena mereka dilarang untuk memakai celana panjang, atau pakaian yang pendek, maka mereka dirugikan. "Yang berbahaya adalah jika mereka (perempuan) memahami kerugian itu dan mulai berpakaian yang tidak pantas. Jika tentara melihat mereka, mereka akan membawa aib bagi keluarga." (Victor, 2008: 102-103)

Kutipan tersebut menjelaskan status perempuan yang dipermasalahkan dalam keturutsertaannya berdemonstrasi. Baju yang panjang merupakan belenggu bagi perempuan untuk bergerak bebas, sehingga apabila perempuan mulai memberontak pada 
tataran tersebut dengan memakai pakaian yang tidak pantas hanya karena merasa dirugikan dengan aturan tersebut, bisa jadi hal sedemikian rupa akan menjadi malapetaka bagi keluarga. Perempuan dianggap sebagai sumber aib jika tidak dijaga dan diperketat dengan aturan-aturan.

Keterlibatan perempuan di arena politik menjadi penting ketika mayoritas penduduk diusir dari tanah air mereka dengan berdirinya Negara Israel pada tahun 1948. Perempuan Palestina terlantar di jalanan bersama keluarga mereka dan menjadi pengungsi di negaranegara yang sekiranya memiliki rasa belas kasih terhadap mereka. Hal tersebut membawa malapetaka yang tak terbayangkan bagi perempuan dan anak-anak. Sementara laki-laki Palestina melibatkan diri mereka dalam pendudukan, perempuan yang tersisa memikul tanggung jawab dalam dua hal, pertama, mereka harus memenuhi peran mereka sebagai penjaga dan perawat bagi keluarga, kerabat dan masyarakat luas, kedua, mereka berpartisipasi dalam perjuangan untuk tanah air dan kembalinya kemerdekaan Palestina. Hal tersebut terihat dalam kutipan berikut,

Dalam perlawanan yang pertama kali terjadi ini, kaum perempuan menulis dan menyebarkannya leaflet, turut serta dalam demonstrasi dan protes, mencoretkan slogan-slogan di dinding, mengibarkan bendera, mendonorkan darah, menolak pemberlakuan jam malam, dan membantu mengorganisasikan sarana alternatif untuk mendidik anak-anak mereka. (Victor, 2008: 1-2)

Kutipan tersebut menggambarkan peran perempuan dalam menghadapi konsekuensi yang mengerikan dari perang yang terjadi akibat konflik antara negara Palestina dan Israel. Mereka ditempatkan pada situasi yang membuat mereka tidak bisa berpegang pada dua tanggung jawabnya. Para perempuan mulai menunjukkan perlawanan mereka dengan cara menulis dan menyebarkan leaflet, ikut berdemonstrasi, memasang sloganslogan, mengibarkan bendera, mendonorkan darah mereka, dan menolak adanya jam malam. Mereka juga mulai mengorganisasikan sarana alternatif untuk mendidik anak-anak mereka sebagai bentuk tanggung jawab mereka atas keluarganya.

Pendapat para ulama menyatakan bahwa perempuan seharusnya ada di dalam rumah bersama keluarganya. Tidak seharunsya perempuan berkeliaran di luar rumah. Para ulama menetapkan standarisasi perempuan bahwa mereka seharusnya melahirkan anak sedini mungkin dan sebanyak-banyaknya. Hal tersebut terdapat dalam kutipan berikut,

Para ulama begitu keras berpendapat bahwa tempat perempuan adalah di dalam rumah bersama-sama keluarganya dan bukan berkeliaran di jalan-jalan tanpa ada yang menemani. Peran perempuan yang tepat adalah melahirkan sedini mungkin dan sesering mungkin. Perempuan diperintahkan untuk kembali pada peran tradisional mereka 
sebagai istri, ibu, dan pengurus rumah tangga; serta memang pada akhirnya perintah itu ditaati. (Victor, 2008: 5)

Dalam kutipan tersebut, para ulama menentang keras jjika perempuan berkeliaran di luar rumah. Para ulama memiliki pendapat yang berbeda, mereka menganjurkan perempuan untuk berdiam diri di rumah daripada harus ikut bertempur karena tugas di ranah domestik tidak kalah penting dengan mengusir Israel yang menjajah Palestina, seperti yang terdapat pada kutipan berikut, "Tidak semua perempuan diciptakan untuk bertempur, dan mereka itu punya tugas-tugas lain yang sama pentingnya dengan mengusir orang-orang yang menduduki tanah kami." (Victor, 2008: 264) Hal tersebut secara tidak langsung membatasi peran serta perempuan dalam aksi bela negara demi melawan pendudukan Israel di negara Palestina.

Selama intifada pertama yang terjadi pada tahun 1987-1993 patisipasi perempuan sangat dituntut, namun karena praktik keagamaan dibatasi oleh Hamas dan Jihad Islam, maka peran perempuan dikembalikan ke tradisi lama, yaitu ke ranah domestik. Di kalangan pemimpin Palestina yang moderat sekalipun telah terjadi kesepakatan untuk membatasi peran serta perempuan dalam intifada pertama, terutama karena mereka khawatir bahwa perbedaan pendapat di antara berbagai kelompok politik dan agama di sepanjang Tepi Barat dan Gaza akan memberikan pengaruh buruk terhadap hasil perjuangan mereka, seperti yang terdapat dalam kutipan berikut,

Kini, dengan meningkatnya pengaruh Hamas dan jihad Islam di sepanjang tepi Barat dan Gaza, tampaknya Arafat dengan berhati-hati mulai mempertimbangkan kembali kebijakannya tentang perempuan dan intifada. Menurut Muhammed Dahalan, Arafat kini berpendapat bahwa kaum perempuan seharusnya tinggal di rumah dan melahirkan anak anak. "Secara khusus ia berbicara lebih serius tentang peran perempuan dalam melahirkan keturunan daripada mendorong mereka untuk menyumbangkan darah demi Palestina," jelas Dahalan. (Victor, 2008: 360)

Berdasarkan kutipan tersebut, upaya perempuan untuk menjadi bagian dari perjuangan indentitas nasional menjadi terpinggirkan. Kebijakan mengenai perempuan dan keikutsertaanya dalam intifada mulai dipertimbangkan kembali. Arafat membicarakan kebijakannya mengenai peran perempuan yang seharusnya berada di area domestik, sehingga keterlibatan perempuan dalam skala nasional diukur hanya melalui tingkat produktivitas mereka dan kemampuan mereka untuk menghasilkan keturunan.

Para kaum perempuan memprioritaskan kepentingan nasional terlebih dahulu dibanding kesetaraannya dengan kaum laki-laki. Kesetaraan menjadi prioritas kedua setelah keberhasilan kepentingan nasional tanpa melihat berbagai alasan, baik secara politis, agama, ataupun psikologis yang menyatukan pandangan kelompok ekstremis dengan pandangan kelompok yang lebih 
moderat dalam masyarakat Palestina, bahkan di kalangan kaum perempuan sendiri. Perubahan kebijakan mengenai perempuan dan keikutsertaan perempuan dalam intifada terjadi begitu cepat dan gamblang.

Ketiga, Dosa versus Pahala. Penghalang dalam komunitas Palestina untuk bunuh diri sebenarnya sangat besar, khususnya dalam budaya mereka, yaitu anggapan masyarakat bahwa bunuh diri adalah dosa besar, namun ada penjelasan religius untuk hal tersebut, ada juga definisi psikologis bahwa barang siapa mati di tangan musuh akan disebut sebagai syahid atau syahidah. Para perempuan meyakini bahwa setelah kematian mereka akan menikmati kehidupan abadi sebagai syahidah, dan posisi mereka akan setara dengan laki-laki seperti dalam kutipan berikut,

Baru setelah itu perempuan-perempuan ini akan menikmati kehidupan abadi yang penuh dengan kebahagiaan, penghormatan, dan kemewahan, serta pada akhirnya diangkat kedudukannya menjadi sederajat dengan kaum laki-laki. (Victor, 2008: xli)

Kutipan tersebut mengindikasikan bahwa terdapat doktrin yang menjanjikan kebahagiaan pada kehidupan setelah kematian. Mereka yang mati akan mendapatkan kebahagiaan yang kekal, mendapatkan penghormatan sebagai syahidah, hidup abadi dengan kemewahan yang tidak mereka dapatkan di dunia. Doktrin tersebut meresap dalam masyarakat bahwa solusi untuk mendapatkan kebahagiaan yang kekal adalah dengan mati bunuh diri.

Budaya kematian yang meresap dalam masyarakat Palestina telah menghancurkan banyak nyawa dan secara tidak langsung menghancurkan generasi bangsa yang akan datang. Masyarakat merasa tidak punya cara lain untuk memperoleh kemenangan, mereka merasa terhimpit dan terjebak dalam kondisi terpuruk di negaranya. Hal tersebut terlihat dalam kutipan berikut, "Budaya kematian telah meresap ke dalam komunitas Palestina dan menghancurkan banyak nyawa, dan lebih dari membuka kemungkinan bagi hancurnya generasi pada masa yang akan datang." (Victor, 2008: xli) Kutipan tersebut menjelaskan bahwa aksi bom bunuh diri yang menjadi budaya dalam masyarakat Palestina sebenarnya merupakan penghancur generasi karena mengorbankan banyak nyawa. Mereka kembali pada tujuan kehidupan yang sebenarnya yaitu kesetiaan, pengorbanan, dan kemuliaan, seperti dalam kutipan berikut.

"Berlawanan dengan pendapat Barat, para syuhada ini mencintai kehidupan lebih daripada orang-orang lain. Sikap ini mungkin aneh bagi orang-orang yang tidak memandang jiwa manusia sebagaimana kebanyakan umat Islam, tetapi tujuan kehidupan kami adalah kesetiaan, pengorbanan, dan kemuliaan..." (Victor, 2008: 191-192) 
Kutipan tersebut menjelaskan bahwa para syuhada lebih mencintai kehidupan dan memandang jiwa manusia seperti kebanyakan umat Islam lainnya. Mereka memiliki tujuan unutk menciptakan kehidupan yang penuh dengankesetiaan, pengorbanan, dan kemuliaan, bukan dengan kekerasan seperti yang mau tidak mau mereka hadapi. Rasa kemanusiaan yang masih mereka yakini adalah Islam sebagai agama yang penuh rahmat bagi semesta Alam.

Para pemimpin spiritual mengeluarkan ketetapan-ketetapan atas nama Allah atau mengumumkan fatwa-fatwa yang langsung diambil dari Al Quran, maka kata-kata mereka yang datang dari Tuhan menjadi hukum, termasuk ketika mereka dibujuk untuk pergi ke surga. Hal tersebut mengindikasikan bahwa kehidupan di bumi ini adalah neraka. Mereka tidak akan melakukannya jika kehidupan mereka baik-baik saja, jika mereka tinggal di lingkungan yang baik, memiliki pendidikan yang layak, bisa hidup terhormat dan punya mata pencarian, tidak akan ada yang memilih kematian. Kondisi pendudukan yang seperti itulah yang mengerikan dan menimbulkan tragedi berdarah, seperti yang terlihat pada kutipan berikut,

Kondisi seperti itu menciptakan pembunuhan dan pelaku bom bunuh diri. Jika mereka [orang-orang Israel] berubah, bangsa Palestina juga akan berubah. Karena situasinya telah sedemikian buruk selama bertahun-tahun, dan karena psikologi anak-anak itu sangat berbeda dengan orang dewasa-begitu mudah dibuat terkesan-maka kita mengalami tragedi. (Victor, 2008: 238)

Kutipan tesebut mengindikasikan kondisi Palestina yang telah sedemikian buruk selama bertahun-tahun lamanya. Tragedi yang penuh dengan pertumpahan darah tidak hanya mengorbankan orang dewasa saja, tetapi juga anak-anak. Kondisi pendudukan atau penjajahan yang sedemikian rupa telah menjadi racikan mematikan yang dibumbui oleh semangat nasionalisme dan ekstremisme religius. Dengan demikian, selalu ada 'resep' tambahan yang mendorong mereka untuk meracik kematian demi negara, Tuhan, dan kehormatannya.

Kepuasan bagi kaum perempuan di surga telah dijanjikan dan janji-janji tersebut membuka peluang untuk menentukan 'nasib' mereka. Konsep kesetaraan, kehormatan, dan kemuliaan dengan begitu indahnya dikemas dan dibayangkan, sehingga sangat mustahil jika para kaum perempuan Palestina tidak tergoda untuk meraih janji-janji surgawi seperti yang tertulis dalam kutipan berikut.

Masing-masing membujuk calon-calon syahidah itu dengan janji-janji yang mudah dipahami, dibayangkan, dan pada akhirnya dipraktikkan karena isu kesetaraan merupakan inti harapan yang benar benar mereka rindukan. (Victor, 2008:

Berdasarkan kutipan tersebut, telah nampak kondisi kehidupan masyarakat Palestina yang penuh keputusasaan, kecintaan terhadap 
kematian, tidak adanya harapan bagi masa depan generasi yang akan datang, dan isu 'kesetaraan' yang merupakan inti harapan yang sangat dirindukan oleh perempuan Palestina adalah bujuk rayu yang akhirnya menarik para calon syahidah untuk melakukan jihad. Hal tersebut merupakan realitas yang berasal dari kekuatan agama dan politis yang kaku, juga dari kedua belah pihak yang bertikai. Namun, keterlibatan perempuan atau gadis muda yang rela mengorbankan dirinya dalam konflik tersebut tetap merupakan isu tersendiri yang memiliki justifikasi dalam kitab suci Alquran, dan realitas dalam ambisi para pemimpin politik dan keagamaan.

\section{B. Profanisasi Jihad dalam Novel Laskar Mawar Karya Barbara Victor}

Dalam Islam, bunuh diri secara harfiah dianggap sebagai tindakan yang dilarang keras oleh agama, sementara kemartiran dipahami sebagai tindakan mulia yang membawa banyak manfaat. Orang-orang yang syahid mencapai kemuliaan abadi melalui mati demi membela agama Allah, mereka dinobatkan sebagai hamba yang telah dikaruniai kehidupan abadi di sisi-Nya. Hal tersebut tertulis dalam kutipan berikut.

Sebelumnya, para pemuka agama belum menafsirkan ketentuan dalam Alquranyang mengutuk bunuh diri dan menganggapnya dosa dengan makna bawa memberikan nyawa dalam aksi mati syahid adalah tanggung jawab dan kewajiban yang dimuliakan oleh Allah dan dihargai sebagai tindakan pengabdian tertinggi kepada agama oleh seluruh hambaNya. (Victor, 2008: 89)

Kutipan tersebut menjelaskan bahwa aksi mati syahid adalah tanggung jawab dan kewajiban yang mulia di sisi Allah. Mati syahid merupakan pengabdian tertinggi kepada agama. Hal tersebut menjadi masalah ketika penjelasan teologis diberikan oleh kelompok-kelompok pejuang Palestina yang berbeda-beda untuk merasionalisasikan motif mereka dalam melakukan bom bunuh diri.

Seorang martir, baik laki-laki mau pun perempuan yang ingin mengorbankan dirinya, tidak semata-mata berujung pada keinginan tanpa niat dan motivasi yang masuk akal. Ada yang berkedok ingin menjadi syuhada, padahal sebenarnya dia telah lelah dan putus asa dengan kehidupannya. Keterputusasaan dan keterpurukan akibat pendudukan di Palestina banyak membuat masyarakat Palestina ingin mengakhiri hidupnya. Oleh karena itu, tindakan bunuh diri tergantung pada niatnya, seperti yang tertera pada kutipan berikut,

Bunuh diri itu tergantung pada niatnya. Jika seorang martir, laki-laki atau perempuan, ingin mengakhiri hidupnya karena ia telah jenuh dengan kehidupannya, itu bisa disebut bunuh diri. Namun, jika ia ingin mengorbankan jiwanya untuk memerangi musuh dan agar mendapatkan pahala dari Allah, dengan derajat yang sama mereka dianggap sebagai syuhada.

(Victor, 2008: 122) 
Berdasarkan kutipan tersebut, tindakan bunuh diri tidak selalu diniati untuk memerangi musuh dalam membela negara, ada juga beberapa yang melakukan tindakan tersebut karena keputusasaan dan kejenuhan seseorang terhadap jalan hidup yang sedang ditempuh. Perbedaannya, jika dia melakukan tindakan tersebut dengan tujuan memerangi musuh dan untuk mendapatkan pahala, maka mereka dianggap syuhada. Meskipun tindakan bunuh diri adalah tindakan yang dilakukan perseorangan, namun Islam memandang tindakan tersebut sebagai kesadaran kolektif, bukan individual. Ada korelasi antara konsep mati syahid dan bom bunuh diri di Palestina. Mereka rela mati membela negara untuk tujuan yang lebih besar dan hal tersebut dilakukan tanpa pamrih.

Bunuh diri telah dilegitimasi sebagai tindakan yang benar oleh masyarakat Palestina sebagai negara Islam. Masyarakat Palestina mengimani bahwa Allah akan memberi ganjaran surga kepada orang-orang yang mati syahid. Asumsi mengenai religiositas di sini membuat bom bunuh diri dianggap hal yang mulia bahkan menjadi cita-cita. Hal tersebut terlihat dalam kutipan berikut.

... orang harus menerima konsep bahwa dalam agama kami dan dalam masyarakat ini, mati sebagai syuhada adalah kehormatan tinggi yang bisa dicapai. (Victor, 2008: 141)

Dalam kutipan tersebut dijelaskan bahwa masyarakat Palestina menerima konsep bunuh diri sebagai syuhada secara sosial dan legal. Hal tersebut dimaknai sebagai tindakan yang heroik untuk melawan pendudukan, dan merupakan suatu kehormatan tertinggi dalam agama Islam, dan secara tidak langsung terdapat sitiran untuk membenarkan aksi bunuh diri.

Palestina menggunakan bom bunuh diri untuk menentang pendudukan Israel. Hal tersebut didukung oleh kelompok penjuang Palestina, organisasi keagamaan seperti Hamas dan Jihad Islam sebagai yang mempopulerkan istilah martir kepada masyarakat Palestina dengan pengaruh bahwa mati di jalan Allah merupakan salah satu cara mengantongi tiket ke surga menuju keabadian, seperti dalam kutipan berikut, "Kesyahidan yang dalam ajaran Islam dijanjikan ganjaran pahala berupa hidup abadi disisi Allah di surga." (Victor, 2008: 54) Doktrin yang menjanjikan ganjaran pahala sebagai penebus dosa dalam kutipan tersebut menawarkan hadiah yang berwujud kehidupan abadi sehingga hal ini menjadi motivasi masyarakat di Palestina.

Islam menyebutkan bahwa para syuhada yang sebenarnya tidaklah mati, seperti pada kutipan berikut, "Dan menurut agama kami, para syuhada itu tidak mati. Mereka hanya pindah ke surga dan menjalani kehidupan yang lebih baik dengan penuh kehormatan." (Victor, 2008: 57) Berdasarkan kutipan tersebut dapat digambarkan betapa indahnya mati di jalan Allah sebagai syuhada, karena dengan mudahnya berpindah ke surga dengan kehidupan yang lebih baik dan penuh kehormatan. Hal tersebut dijadikan motivasi oleh sebagian besar masyarakat Palestina, seperti dalam kutipan berikut, "Lebih baik mati sebagai syahidah 
daripada hidup dalam kehinaan." (Victor, 2008: 26) Kutipan tersebut mencerminkan, betapa hinanya hidup dalam pendudukan, sehingga berjihad hingga mati syahid layak dijadikan pilihan terbaik.

Konsep jihad sebagai kewajiban individual dan kultural dan kematian syahid dalam masyarakat telah berkontribusi besar dalam kasus bom bunuh diri perempuan. Terdapat pengaruh religius yang besar dalam masyarakat Palestina, dan itulah alasannya mengapa begitu banyak pelaku bom bunuh diri bermunculan. Tetapi, ada juga yang merasa keberatan jika para pemimpin agama berkata bahwa perempuan yang melakukan aksi tersebut pada akhirnya akan memperoleh posisi yang setara dengan laki-laki. Semua orang setara dalam kematian, baik orang kaya, miskin, bangsa Arab, Yahudi, atau Kristen, semua setara. Hal tersebut dipaparkan dalam kutipan berikut.

"Kami ini orang-orang yang memegang prinsip, dan menurut agama kami, seorang perempuan Muslim diizinkan untuk turut berjihad dan berjuang melawan musuh yang menginvasi tanah suci. Nabi pernah melakukan undian untuk menentukan siapa di antara kaum perempuan yang bisa menyertainya berjihad. Dan Nabi selalu menekankan hak perempuan untuk turut berjihad," demikian kata Syaikh Yassin. (Victor, 2008:

35)

Kutipan tersebut menjelaskan bahwa hak perempuan untuk turut berjihad setara dengan laki-laki. Perempuan mendapatkan kesetaraannya baik di dunia mau pun di surga. Tetapi, yang lebih menguatkan lagi adalah doktrin bahwa di surga kaum perempuan merasa puas, sebab di sana tidak ada persaingan antara laki-laki dan perempuan. Setiap orang memperoleh apa yang mereka inginkan, dan mereka menjadi tuan bagi diri mereka sendiri. Mereka mencapai kepuasan mutlak setelah kematiannya. Di sinilah wewenang pemimpin agama untuk mengubah justifikasi religius tentang kesyahidan menjadi sebuah mandat sosial dan kultural bagi anggota masyarakat, khususnya kaum perempuan.

Ketika umat Islam diserang di rumah mereka sendiri dan tanah mereka dirampok, maka jihad demi Allah berubah menjadi kewajiban individu masing-masing, sama saja antara laki-laki dan perempuan. Dalam kasus semacam itu, aksi mati syahid menjadi kewajiban yang utama dan merupakan bentuk jihad tertinggi dalam Islam. Mati demi Palestina dan mati demi mencapai kedudukan di sisi Allah di surga telah menjadi tujuan yang sangat bernilai bagi sebagian orang dan kebanyakan dari mereka sangat mengagumi aksi semacam itu. Janji-janji surgawi bagi seorang yang syahid maupun syahidah sangat menggiurkan, seperti pada kutipan berikut.

Dari saat darah menetes untuk pertama kalinya, seorang syahid tidak akan merasakan sakitnya luka, dan dimanfaatkan segala perbuatan buruknya: dia melihat tempat tinggalnya di surga: dia diselamatkan dari siksa kubur: dia diselamatkan dari ketakutan akan hari pembalasan: dia akan menikahi 72 
perempuan cantik permata hitam: dia menjadi jalan bagi tujuh puluh kerabatnya untuk mencapai surga: dia memperoleh mahkota kebesaran yang permatanya lebih bagus daripada dunia ini dan segala isinya. Ketika aku tanya Syaikh Yassin apa yang diterima oleh Syahidah di surga, ia menjawab bahwa mereka menjadi "lebih cantik daripada 72 gadis tadi... jika ia belum menikah," lanjutnya, "mereka dijamin memperoleh seorang suami yang suci di surga, dan tentu saja, mereka berhak membawa tujuh puluh kerabat untuk menyertainya di sana tanpa penderitaan karena siksa kubur." (Victor, 2008: 144)

Jelas disebutkan dalam kutipan tersebut bahwa kematian merupakan suatu hal yang mulia. Dalam hal ini, agama atau mereka yang menggunakan agama demi mencapai tujuan-tujuan itu akan menjelaskan apa yang terjadi di surga setelah kematian, dan mereka membuat hal tersebut menjadi nampak begitu memesona dibandingkan dengan kehidupan di bawah pendudukan.

Terdapat doktrin agama yang menyebutkan bahwa di surga adalah tempat yang membuat para perempuan merasa puas karena mereka setara dengan laki-laki, tidak ada pembeda dan persaingan di antara keduanya. Para perempuan di surga mencapai kepuasan mutlak setelah kematiannya, seperti pada kutipan berikut.

Di surga, kaum perempuan merasa puas. Itulah hal yang paling penting. Sebab, di sana tidak ada persaingan antara laki-laki dan perempuan. Setiap orang memperoleh apa yang mereka inginkan, dan mereka menjadi tuan bagi diri mereka sendiri. Mereka mencapai kepuasan mutlak setelah kematian.

(Victor, 2008: 147)

Kutipan tersebut menunjukkan bahwa kepuasan mutlak perempuan yang mereka dapatkan di surga kelak dikarenakan tidak adanya persaingan antara laki-laki dan perempuan, mereka semua setara. Semua yang mereka inginkan akan terpenuhi. Hal tersebutlah yang terus menerus mendorong mereka untuk berkeinginan melakukan aksi mati syahid, seperti pada kutipan berikut, "Ketika seorang syahid meninggal, dia akan meraih kebahagiaan abadi..." (Victor, 2008: 192) Jika mati demi Palestina dan mati demi mencapai kedudukan di sisi Allah di surga telah menjadi tujuan yang sangat bernilai bagi sebagian orang, maka kebanyakan dari mereka sangat mengagumi aksi-aksi semacam itu. Berdasarkan penjabaran tersebut, dapat dimaknai bahwa jihad di sini bukan lagi tindakan yang sakral, namun berubah menjadi profan.

\section{Di Balik Pembongkaran Makna Jihad}

Bunuh diri merupakan hal tabu dan jika hal tersebut sampai terjadi maka pelakunya dianggap tidak beradab, namun tindakan bunuh diri menggunakan bom sangat umum dilakukan di Palestina. Secara khusus, tindakan bom bunuh diri di Palestina dipelopori oleh sejumlah organisasi keagamaan yang menyebut kelompoknya 
sebagai kelompok pejuang Palestina seperti beberapa di antaranya, Hamas dan Jihad Islam. Selama ini, orang-orang yang melakukan tindakan bunuh diri dianggap memiliki penyakit mental, karena hal tersebut merupakan tindakan yang tidak rasional. Setiap orang memiliki tujuan hidup yang sama, yaitu mencapai kebahagiaan. Bagaimana mungkin kebahagiaan itu diraih dengan kematian? Karena tidak ada yang mengetahui kehidupan setelah kematian.

Durkheim mengatakan bahwa selalu ada alasan di balik setiap tindakan bunuh diri, meskipun tidak rasional (Durkheim, 1951: 12). Meskipun mereka punya alasan yang tidak rasional, hal tersebut tetap merujuk sebagai tindakan seseorang yang sudah putus asa dalam menjalani hidupnya. Tindakan bom bunuh diri yang didoktrin sebagai jihad jelas merupakan tindakan yang tidak rasional dan kebanyakan pelakunya adalah orang-orang putus asa yang dihadapkan oleh situasi yang mendesak mereka untuk melakukan tindakan radikal tersebut.

Beberapa beranggapan bahwa tindakan bunuh diri di tengah konflik yang terjadi antara negara Israel dan Palestina adalah tindakan yang logis. Kelompok pejuang Palestina melegitimasi tindakan bom bunuh diri sebagai ekspresi untuk melawan pendudukan Israel. Prinsip di balik tindakan bom bunuh diri ini berkaitan erat dengan semangat nasionalis. Bom bunuh diri dijadikan senjata pilihan bagi kelompok-kelompok pejuang Palestina dalam membela negaranya untuk melawan pendudukan Israel. Meskipun teknologi sudah berkembang, tersedia bahan peledak yang bisa diledakkan dari jauh dan dapat menyebabkan kerusakan lebih cepat tanpa harus mengorbankan nyawa, namun ada saja yang secara sukarela menjadi pelaku bom bunuh diri.

Makna jihad yang ditampilkan dalam novel Laskar Mawar karya Barbara Victor merupakan makna jihad dari sudut pandang lain. Disebut jihad dari sudut pandang lain karena telah terjadi pembongkaran terhadap konstruksi jihad yang telah ada. Pembongkaran terhadap kemapanan tersebut meniadakan oposisioposisi biner yang merupakan batas antara sesuatu yang sakral dan yang profan.

Niat berjihad dalam teks-teks yang telah disebutkan dan diproklamirkan untuk membela agama dan negara yang semula murni untuk mendapat ridho Allah menjadi tidak murni karena niatnya telah bercampur dengan niat-niat yang lain, seperti ingin mendapatkan ketenaran dengan berkedok ingin menjadi syuhada, yang sebenarnya merupakan pelarian atas kejenuhan dalam menjalani hidup di tengah konflik negara Palestina.

Dengan demikian, fenomena pengeboman yang terjadi di tengah konflik Palestina dan Israel diklaim sebagai tugas mulia bagi seorang hamba Allah, hal tersebut merupakan jihad dalam bentuk yang baru. Dengan mendekonstruksi makna jihad, maka dapat diketahui makna jihad yang selama ini tertunda. Jihad dalam bentuk bom bunuh diri yang belum pernah dilegalkan, dapat dijadikan pertimbangan sebagai penyelesaian konflik yang terjadi. 
Melibatkan diri dalam aksi tersebut sama halnya telah berjihad di jalan Allah.

Tindakan bom bunuh diri dan sikap berani mati merupakan hal penting dari perjuangan suci yang disebut jihad. Para jihadis lebih berekspektasi mengenai kehidupan yang ada setelah kematian. Kematian demi menegakkan dan membela agama adalah tujuan yang sangat mulia, karena siapapun yang mengimani hal tersebut memahami bahwa keabadian hidup hanya di akhirat. Namun, sikap tersebut tidak memperhitungkan akibat dari tindakan yang nyatanya banyak menelan korban kemanusiaan.

Keyakinan mengenai kehidupan setelah kematian cenderung mengarahkan para penganutnya pada tindakan-tindakan yang berlawanan dengan realitas sosial. Tertanam di pikiran masyarakat bahwa tindakan tersebut merupakan bentuk penghambaan pada Tuhan tanpa melihat realitas sosial yang ada, sehingga lebih mengedepankan tindakan yang berwujud kekerasan, padahal agama tidak mengamini praktik kekerasan dan tindakan anti kemanusiaan.

Fenomena tersebut terjadi karena dilandasi oleh keyakinan agama bahwa terdapat pembenaran dalam melakukan tindakan tersebut karena mengandung makna jihad untuk menyudahi ketidakadilan yang terjadi di muka bumi, terutama di negara berkonflik. Sitiran keyakinan agama tersebut tidak sepenuhnya salah, ketidakadilan memang harus diiakhiri, tetapi yang menjadi persoalan terletak pada kesempitan pola pikir dalam menginterpretasikan doktrin-doktrin agama.

Tindak kekerasan berupa bom bunuh diri adalah hal yang irasional karena agama tidak mengehendaki adanya kekerasan. Citra agama menjadi luntur dengan tindakan yang cenderung mengarah kepada kekerasan. Agama dijadikan tempat pelarian bagi manusia yang merasa terasing. Oleh karena itu, hal yang dilakukan para jihadis dengan dalih agama tidak lain adalah suatu bentuk pembunuhan jati diri kemanusiaan.

Sebagian masyarakat menganggap bahwa tindakan bom bunuh diri merupakan jihad di jalan Allah, pelaku tindak bom bunuh diri dinobatkan sebagai orang yang mati syahid, bahkan banyak sitiran untuk mendukung dan berpartisipasi dalam tindakan tersebut, tetapi benarkah tindakan bom bunuh diri merupakan jihad yang sesungguhnya? Kenyataannya, fenomena bom bunuh diri tidak membuat musuh menjadi jera dan berhenti melakukan penyerangan, justru mereka semakin gigih dengan kebrutalannya dan semakin membabi buta.

Aksi bela negara yang dilakukan untuk menghabisi musuh tidak sebanding dengan banyaknya musuh. Semakin musuh itu dilawan, justru ia akan semakin membalas dengan lebih kejam dan brutal. Sebagaimana yang dilakukan oleh Israel kepada masyarakat Palestina. Berdasarkan hal tersebut, maka tindakan bom bunuh diri tidak bermanfaat bagi kaum muslim maupun orang-orang yang diledakkan pada barisan tersebut.

Selain melihat fenomena, perkara-perkara tersebut membutuhkan perenungan dan juga pertimbangan dalam setiap 
kondisinya. Siapa saja yang meledakkan diri dengan cara memasang bahan peledak di tubuhnya dengan tujuan untuk meledakkan dirinya bersama musuh adalah orang yang membunuh dirinya sendiri, hal tersebut merupakan tindak kekerasan. Hal tersebut sangat jauh dari nilai-nilai kemanusiaan dan keagamaan. Mati ketika berperang dengan mati karena diniati untuk bunuh diri adalah hal yang berbeda.

Jihad merupakan suatu kewajiban dalam Islam, namun pandangan yang keliru terhadap jihad dalam Islam hingga saat ini masih banyak dijumpai baik di kalangan muslim maupun non muslim. Pandangan yang keliru terhadap pemaknaan jihad cenderung mendorong kepada perbuatan radikal bagi kalangan muslim, sedangkan bagi non muslim dapat berdampak antipati terhadap Islam. Dengan demikian, fenomena bom bunuh diri merupakan fenomena yang tidak terlepas dari pergerakan Islam garis keras dan merupakan faktor yang paling signifikan pada konflik Palestina dan Israel.

Seorang jihadis yang menyetorkan nyawanya untuk melaksanakan jihad dengan kemungkinan besar tidak terselamatkan mempunyai ideologi tersendiri sehingga dia merasa bertindak yang membawa manfaat besar bagi agama dan negaranya. Tindakan seorang jihadis yang melilitkan peledak pada tubuhnya untuk menyerang musuh dan kemungkinan besar ikut terbunuh merupakan tindakan bunuh diri yang konyol. Jadi, jika ada pendapat yang membenarkan tindakan bom bunuh diri, maka hal tersebut merupakan pendapat yang keliru dan sangat mudah untuk dibantah, karena sebaik apapun niat yang diikuti oleh tindakan yang tidak baik dapat berpotensi menghancurkan.

Tindakan bom bunuh diri yang didoktrin sebagai jihad adalah tindakan yang merugikan karena keputusan yang diambil tidak berdasarkan pertimbangan yang matang. Mereka yang melakukan tindakan tersebut sebenarnya tidak berpikir panjang mengenai dampaknya jika dilihat dari sisi kemanusiaan. Bahkan agama tetap mengedepankan humanisme dalam bermasyarakat. Nilai kemanusiaan seharusnya dijunjung tinggi untuk membentuk masyarakat yang humanis penuh perlindungan, bukan sebaliknya.

Jika mengedepankan humanisme, tindak kekerasan tidak dianjurkan dengan alasan apapun. Tidak ada yang membenarkan tindak kekerasan dari sisi kemanusiaan. Tindakan bom bunuh diri bukanlah cara yang positif dalam berjihad untuk menghadapi konflik yang terjadi, justru tindakan tersebut membentuk penilaian negatif terhadap Islam. Hal tersebut mengundang kesalahpahaman secara global, meskipun citra negatif hanya tertuju pada beberapa kelompok Islam tertentu.

Dekonstruksi yang diciptakan oleh pemaknaan baru atas jihad bom bunuh diri berpotensi menyesatkan. Terlepas dari berbagai motivasi yang melatarbelakangi tindakan tersebut, kekerasan atau kebrutalan adalah tindakan yang bertentangan dengan nilai dasar kemanusiaan dan nilai universal agama. Pada hakikatnya, agama manapun bermuatan nilai yang merujuk pada kepedulian tinggi 
terhadap nilai kemanusiaan dan perdamaian. Oleh karena itu, sangat penting kembali memaknai agama pada nilai kemanusiaan karena agama seharusnya menjadi rahmat bagi semua makhluk yang hidup di alam semesta.

\section{SIMPULAN}

Berdasarkan hasil analisis yang dilakukan terhadap novel Laskar Mawar karya Barbara Victor, maka dapat disimpulkan bahwa terdapat pembongkaran terhadap konstruksi jihad yang telah ada, di antaranya: (1) operasionalisasi oposisi biner mengenai jihad yang meliputi; Pertama, laki-laki versus perempuan. Jihad yang seharusnya dilakukan oleh laki-laki, juga dilakukan oleh perempuan. Kedua, privat versus publik. Peran perempuan yang turut andil dalam berjihad, semula peran perempuan berada di ranah privat atau domestik, namun dalam novel ini para perempuan pun berada di ranah publik. Ketiga, dosa versus pahala. Tindakan bom bunuh diri yang selama ini dianggap dosa, ternyata justru terdapat sitiran untuk melakukan tindakan tersebut yang didoktrin sebagai jihad, (2) profanisasi jihad yang menyebutkan bahwa bunuh diri dianggap sebagai tindakan yang dilarang keras oleh agama, sementara kemartiran dipahami sebagai tindakan mulia yang membawa banyak manfaat. Makna jihad yang awalnya sakral, berubah menjadi profan. Berdasarkan seluruh penjelasan yang telah dipaparkan, pembongkaran terhadap konstruksi jihad tersebut melahirkan pemaknaan bahwa jihad bom bunuh diri merupakan tindakan yang tidak sesuai dengan nilai kemanusiaan dan nilai universal agama. Dekonstruksi atas jihad bom bunuh diri berpotensi menyesatkan. Tindakan bom bunuh diri bukanlah cara yang positif untuk menghadapi konflik, justru tindakan tersebut membentuk penilaian negatif terhadap Islam.

Penelitian novel Laskar Mawar karya Barbara Victor diharapkan dapat menjadi referensi bagi penelitian selanjutnya yang berkaitan dengan isu religiositas dan dapat diangkat ke ranah yang lebih luas dengan membandingkan penelitian-penelitian serupa, yaitu mengenai jihad dari berbagai wilayah lain. Selain itu, masyarakat diharapkan dapat memahami tindakan jihad secara kontekstual dan tidak mudah terprovokasi terhadap wacana ekstrem mengenai jihad, apalagi membenarkan aksi kekerasan yang mengatasnamakan agama. Dengan demikian, masyarakat diharapkan dapat melihat fenomena tersebut dari berbagai sisi dan dapat menyikapi hal tersebut secara bijaksana.

\section{DAFTAR PUSTAKA}

Al Uyairi, S. Y. 2007. Muslimah Berjihad: Peran Wanita di Medan Jihad. Solo: Media Islamika.

Creswell, J. W. 2009. Research Design: Pendekatan Kualitatif, Kuantitatif, dan Mixed. Yogyakarta: Pustaka Pelajar.
Dematra, D. 2009. Demi Allah Aku Jadi Teroris. Jakarta: Gramedia.

Deutscher, P. 2006. How to Read Derrida. New York: Norton \& Company.

Durkheim, E. 1951. Suicide. New York: Free Press. 
Gambetta, D., \& Hertog, S. 2016. Engineers of Jihad. United States of America: Princeton University Press.

Goldschmit, M. 2003. Jacques Derrida: Une Introduction. Paris: La Decouverte.

Haryatmoko. 2016. Membongkar Rezim Kepastian Pemikiran Kritis PostStrukturalis. Yogyakarta: Kanisius.

Jatmika, S. 2009. Pengantin Bom. Yogyakarta: Liber-Plus.

Moleong, L. J. 2007. Metodologi Penelitian Kualitatif. Bandung: PT Remaja Rosdakarya.

Muntaha, M. 2007. Jihad Terindah. Jakarta: Rabitha Press.
Neuman, L. W. 2004. Qualitative and Quantitative Social Research. Needham Heights, Massachusetts: Allyn and Bacon.

Sumbulah, U. 2005. Agama dan Kekerasan (Menelisik Akar Kekerasan dalam Tradisi Islam). Philosophica et Theologica.

Triana, N. 2009. Perlindungan Perempuan dan Anak Ketika Perang dalam Hukum Humaniter Internasional. YINYANG, 320334.

Victor, B. 2008. Laskar Mawar. Bandung: Mizan Media Utama.

Wellek, R. 2014. Teori Kesusastraan. Jakarta:

Gramedia. 